Nama : Nyoman Ayu Shandy

NRP : 130118088

\title{
Pengaruh Informasi teknologi terhadap kinerja perusahaan
}

Pengaruh informasi teknologi terhadap hubungan antara strategi dan kinerja perusahaan memnungkinkan perusahaan untuk mengembangkan kemampuannya di berbagai bidang. Dalam investasi dalam teknologi memungkinkan perusahaan untuk mengembangkan kemampuan mereka dengan akuisisi informasi aktif. Informasi teknologi membuat kinerja perusahaan dapat dihubungkan dengan baik dengan faktor organisasi lain seperti SO. Dengan adanya informasi teknologi UKM dimungkinkan mendapat informasi tentang kebutuhan pelanggan yang bisa membuat perusahaan sadar akan adanya pasar baru dan perkembangan teknologi menjadi nilai bisnis.

Kombinasi antara kelompok kustomer dan Informasi Teknologi dapat meningkatkan kinerja perusahaan agar kinerja mereka dapat ditingkatkan. Informasi Teknologi memungkinkan UKM untuk mengembangkan kemampuannya di berbagai bidang, termasuk aliansi, pengembangan produk, pemasaran, dan merger. UKM perlu memahami tahap keunggulan kompetitif serta kemampuan mereka untuk mengelola inovasi di bawah turbulensi lingkungan yang tinggi, karena banyak perusahaan berumur pendek. Dengan perubahan teknologi yang dapat diprediksi, UKM dapat memanfaatkan teknologi untuk melaksanakan strateginya. Namun, di bawah turbulensi teknologi yang sangat dinamis, UKM akan mengalami strategi berbasis peluang (Pratono, 2016) 
Bibliography

Pratono, A. H. (2016). Strategic orientation and information technological turbulence: Contingency perspective in SMEs. Business Process Management Journal, 22(2), 368-382. 